A N N A L E S

UNIVERSITATIS MARIAE CURIE-SKŁODOWSKA

LUBLIN - POLONIA

VOL. LXII, 2

SECTIO G

2015

ANNA REDA-CISZEWSKA

\title{
Uzasadnienie wypowiedzenia umowy o pracę na czas określony
}

Justified Dismissal in Case of Fixed-Term Employment

\section{UWAGI WSTEPNE}

Ustawodawca dopuszcza, co do zasady, wypowiedzenie tylko dwóch umów o pracę: na okres próbny i na czas nieokreślony, przy czym tylko w przypadku tej drugiej pracodawca został zobowiązany do wskazania uzasadnionej przyczyny wypowiedzenia. Wątpliwości nadal budzi wypowiedzenie umowy o pracę na czas określony na podstawie art. 33 k.p. Temat ten, pomimo upływu pewnego czasu od wyroku Trybunału Konstytucyjnego z dnia 2 grudnia 2008 roku ${ }^{1}$, pozostaje nadal aktualny, zwłaszcza z uwagi na odmienny kierunek orzecznictwa Trybunału Sprawiedliwości Unii Europejskiej i jego wyrok z dnia 13 marca $2014 \mathrm{roku}^{2}$. Umowa o pracę na czas określony to temat wciąż aktualny także z uwagi na brak w prawie polskim skutecznej regulacji ograniczającej możliwość zatrudnienia na czas określony3.

Warto zastanowić się nad przyszłym kształtem regulacji w zakresie umów o pracę na czas określony pod względem jej zgodności z prawem międzynarodo-

1 Wyrok Trybunału Konstytucyjnego z dnia 2 grudnia 2008 roku, P 48/07, OTK ZU 2008, nr 10A, poz. 173 ze zdaniem odrębnym sędzi T. Liszcz.

2 Wyrok Trybunału Sprawiedliwości Unii Europejskiej z dnia 13 marca 2014 roku w sprawie C-38/13, http://curia.europa.eu/juris/document/document.jsf?text $=\&$ docid=149140\&pageIndex $=0$ \&doclang=PL\&mode $=1$ st\&dir=\&occ=first\&part=1\&cid=458269 [data dostępu: 02.02.2015].

3 Ostatni projekt zmian: www.mpips.gov.pl/bip/projekty-aktow-prawnych/projekty-ustaw/ prawo-pracy/projekt-ustawy-o-zmianie-ustawy---kodeks-pracy-oraz-niektorych-innych-ustaw-1 [data dostępu: 02.02.2015]. Stan prawny być może ulegnie zmianie do czasu publikacji tego artykułu, jednak w obecnej wersji projektu nie przewiduje się wprowadzenia obowiązku uzasadnienia wypowiedzenia umowy o pracę na czas określony. Projekt jako zasadę przewiduje dopuszczalność wypowiedzenia umowy o pracę na czas określony. 
wym i europejskim oraz poświęcić więcej uwagi propozycji T. Liszcz zawartej w zdaniu odrębnym do przywołanego wyroku Trybunału Konstytucyjnego, która wskazywała na konieczność wprowadzenia obowiązku uzasadnienia wypowiedzenia umowy o pracę na czas określony.

\section{OCHRONA PRZED NIEUZASADNIONYM ZWOLNIENIEM W PRAWIE MIĘDZYNARODOWYM I EUROPEJSKIM}

Omawiając temat obowiązku uzasadnienia wypowiedzenia umowy o pracę na czas określony, należy zacząć od dorobku Międzynarodowej Organizacji Pracy (dalej: MOP). W 1982 roku uchwalono Konwencję nr $158^{4}$ oraz zalecenie $\mathrm{nr} 166$ dotyczące rozwiązania stosunku pracy z inicjatywy pracodawcy 5 . Mimo że konwencja nie została ratyfikowana przez Polskę, to można mówić o jej pośrednim wpływie na krajowe prawodawstwo na podstawie Deklaracji MOP z 1998 roku. Zgodnie z jej treścią wszyscy członkowie, nawet jeśli nie ratyfikowali odpowiednich konwencji, mają obowiązek poszanowania, promowania oraz realizacji zasad dotyczących praw stanowiących przedmiot konwencji, uznawanych za podstawowe ${ }^{6}$. Konwencja przewiduje system ochrony przed zwolnieniem z pracy z inicjatywy pracodawcy. Konwencja nr 158 szeroko odnosi się do pojęcia rozwiązania stosunku pracy z pracownikiem i wskazuje w tym przypadku na rozwiązanie stosunku pracy następujące $\mathrm{z}$ inicjatywy pracodawcy (art. 3 konwencji).

Odnosząc się do przyczyn rozwiązania umowy o pracę, konwencja dzieli je na dwie grupy: przyczyny dotyczące pracownika i dotyczące pracodawcy (art. 4 konwencji). Jednocześnie zawiera katalog negatywnych przyczyn rozwiązania stosunku zatrudnienia. Nie mogą stanowić ważnych przyczyn rozwiązania stosunku pracy m.in.: a) przynależność związkowa lub udział w działalności związkowej poza godzinami pracy albo - za zgodą pracodawcy - w godzinach pracy, b) fakt ubiegania się o mandat przedstawiciela pracowników, sprawowanie go obecnie lub w przeszłości, c) fakt złożenia skargi lub udział w postępowaniu przeciwko pracodawcy ze względu na zarzut rzekomego naruszania ustawodawstwa albo odwołanie się do właściwych władz administracyjnych, d) rasa, kolor skóry, płeć, stan rodzinny, obowiązki rodzinne, wyznanie, poglądy polityczne, przyna-

4 Konwencję ratyfikowała m.in. Hiszpania, która również boryka się z wysokim wskaźnikiem zatrudnienia na czas określony. Konwencja nie należy jednak do grupy konwencji fundamentalnych.

5 Treść konwencji i zalecenia można odnaleźć na stronie www.ilo.org/global/standards/lang--en/index.htm [data dostępu: 08.02.2015].

6 Deklaracja Międzynarodowej Organizacji Pracy dotycząca podstawowych zasad i praw w pracy oraz działania uzupełniające, przyjęta przez Konferencję Ogólną MOP w dniu 18 czerwca 1998 roku. Zob. www.ilo.org/public/english/standards/declaration/declaration_polish.pdf [data dostępu: 02.02.2015]. 
leżność narodowa lub pochodzenie społeczne, e) nieobecność w pracy w czasie urlopu macierzyńskiego (art. 5 konwencji).

Zgodnie $\mathrm{z}$ art. 2 ust. 1 Konwencji $\mathrm{nr} 158$ ma ona zastosowanie do wszystkich dziedzin działalności gospodarczej i do wszystkich zatrudnionych osób. Warto jednak zaznaczyć już na początku, że wyjątki mogą dotyczyć m.in. umów terminowych. $Z$ zakresu zastosowania konwencji można wyłączyć: a) pracowników zatrudnionych na podstawie umowy o pracę na czas określony lub umowy o dzieło, b) pracowników zatrudnionych na okres próbny lub niemających wymaganego stażu, pod warunkiem, że długość tych okresów będzie określona z góry i w rozsądnym wymiarze, c) pracowników zatrudnionych dorywczo i na krótki okres.

Ustawodawca międzynarodowy dostrzega niebezpieczeństwo nadużywania umów o pracę na czas określony do obchodzenia unormowania Konwencji nr 158 i wskazuje na konieczność zapewnienia odpowiednich gwarancji zabezpieczających przed uciekaniem się do umów o pracę na czas określony, których celem jest unikanie przyznawania ochrony wynikającej z tej konwencji (art. 2 ust. 3 konwencji, także powtarza to zalecenie 166). Już w 1995 roku zwracano uwagę na to, że regulacja konwencji zawiera sprzeczne rozwiązania, a stabilne zatrudnienie (umowy o pracę na czas nieokreślony) jest zastępowane przez samozatrudnienie, przez co cel konwencji pozostaje zniweczony ${ }^{7}$. Z informacji przedstawionych w dokumentach MOP wynika, że niektóre z państw, które ratyfikowały Konwencję $\mathrm{nr} 158 \mathrm{MOP}$, wymagają także w przypadku umów terminowych wskazania ważnej przyczyny rozwiązania umowy o pracę․ Dosyć dużą rolę może odegrać dialog społeczny w ramach procesu wdrażania rozwiązań konwencji do prawa krajowego. Komitet Ekspertów już w 1995 roku zachęcał Hiszpanię do wspierania trójstronnego dialogu społecznego w celu wypracowania rozwiązań gwarantujących pracownikom terminowym odpowiednią ochronę przed zwolnieniem'.

Kolejnym dokumentem odnoszącym się do problematyki ochrony przed zwolnieniem pracownika jest Europejska Karta Społeczna z dnia 18 października 1961 roku oraz Zrewidowana Europejska Karta Społeczna z dnia 3 maja 1996 roku $^{10} . \mathrm{Z}$ art. 4 ust. 4 EKS wynika jedynie, że w celu zapewniania skutecznego wykonywania prawa do sprawiedliwego wynagrodzenia należy uznać prawo wszystkich pracowników do rozsądnego okresu wypowiedzenia. Przepis ma za-

7 ILO, Protection Against Unjustified Dismissal, General Survey on the Termination of Employment Convention (No. 158) and recomendation (No. 166), Geneva 1995, § 56, s. 23.

8 Zob. ILO, Termination of Employment Instruments, Background paper for the Tripartite Meeting of Experts to Examine the Termination of Employment Convention, 1982 (No. 158), and the Termination of Employment Recommendation, 1982 (No. 166), Geneva 2011, s. 67.

9 Committee of Experts on the Application of Conventions and Recommendations, General Survey - Protection against unjustified dismissal (1995), direct request - Spain (1995).

10 Polska dotychczas ratyfikowała jedynie Europejską Kartę Społeczną z 1961 roku (Dz.U. z 1999 roku, nr 8, poz. 67), dalej: EKS oraz ZEKS. 
stosowanie do wszystkich umów o pracę, również umów terminowych, ale Karta nie wyłącza różnicowania okresów wypowiedzenia umów o pracę pod warunkiem, że będą one rozsądne ${ }^{11}$. Szerzej do kwestii ochrony przed wypowiedzeniem odnosi się art. 24 ZEKS przewidujący, że państwa-strony zobowiązują się uznać: a) prawo pracowników do tego, by nie być zwolnionym bez uzasadnionego powodu związanego z predyspozycjami lub zachowaniem lub opartego na konieczności związanej z działalnością przedsiębiorstwa, zakładu lub służby, b) prawo pracowników zwolnionych bez uzasadnionego powodu do odpowiedniego zadośćuczynienia lub do innego odpowiedniego wynagrodzenia szkody. W tym celu państwa-strony zobowiązują się zapewnić, że pracownik, który uważa, że został zwolniony bez uzasadnionego powodu, będzie miał prawo odwołania się do bezstronnego organu.

Kolejnym ważnym dokumentem, do którego należy się odnieść, jest powiązana ze Zrewidowaną Europejską Kartą Społeczną - Karta Praw Podstawowych Unii Europejskiej (Dz.U. UE C 2007/303/1; dalej: KPPUE). Zgodnie z art. 30 Karty Praw Podstawowych UE każdy pracownik ma prawo do ochrony w przypadku nieuzasadnionego zwolnienia z pracy, zgodnie z prawem wspólnotowym oraz ustawodawstwami i praktykami krajowymi. KPPUE uznaje prawo pracowników do ochrony przed nieuzasadnionym zwolnieniem za jedno z praw podstawowych. Art. 30 Karty może być uznawany za zaskakujący, zwłaszcza że od 2000 roku widoczny jest proces deregulacji w obszarze ochrony zatrudnienia w państwach europejskich ${ }^{12}$.

Przepis KPPUE, choć przewiduje ochronę dla każdego pracownika, pozostaje ogólny i niejasny. W wyjaśnieniach do Karty odwołano się do powoływanego już art. 24 ZEKS oraz do dwóch dyrektyw unijnych ${ }^{13}$, mianowicie do dyrektywy 2001/23/WE w sprawie ochrony praw pracowniczych w przypadku przeniesienia własności przedsiębiorstw oraz dyrektywy 80/987/EWG w sprawie ochrony pracowników na wypadek niewypłacalności pracodawcy, zmienionej dyrektywą 2002/74/WE. Są to dyrektywy związane z funkcjonowaniem pracodawcy jako podmiotu zatrudniającego pracownika. Trudno jednak poszukiwać w postanowieniach tych dyrektyw podstawy dla obowiązku uzasadnienia rozwiązania stosunku pracy w każdym przypadku. Niewątpliwie takie przypadki uzasadniające obowiązek wskazania przyczyny rozwiązania umowy o pracę łączą się ze zmianami organizacyjno-prawnymi po stronie pracodawcy czy też niewypłacalnością pracodawcy. Nie wspomina o obowiązku uzasadnienia wypowiedzenia umowy o pracę na czas określony również dyrektywa 99/70, dotycząca umów o pracę na

11 A.M. Świątkowski, Karta Praw Społecznych Rady Europy, Warszawa 2006, s. 154-155.

12 I. Schömann, Labour Law Reforms in Europe: Adjusting Employment Protection Legislation for the Worse?, "Working Paper" 2014.02, Brussels 2014, s. 5.

13 Zob. wyjaśnienia dotyczące Karty Praw Podstawowych (Dz.Urz. 2007/C 303/02). 
czas określony ${ }^{14}$. Zawiera ona jedynie przepis dotyczący zakazu dyskryminacji osób zatrudnionych na podstawie umów o pracę na czas określony (klauzula 4).

Trzeba także podkreślić, że Karta Praw Podstawowych ma zastosowanie tylko w zakresie stosowania prawa unijnego i nie modyfikuje kompetencji określonych w traktatach. W świetle art. 51 ust. 1 postanowienia Karty mają zastosowanie do instytucji, organów i jednostek organizacyjnych Unii przy poszanowaniu zasady pomocniczości oraz do Państw Członkowskich wyłącznie w zakresie, w jakim stosują one prawo Unii. Szanują one zatem prawa, przestrzegają zasad i popierają ich stosowanie zgodnie ze swymi odpowiednimi uprawnieniami i w poszanowaniu granic kompetencji Unii powierzonych jej w traktatach. Art. 51 ust. 2 stanowi, że nie ustanawia ona żadnego nowego uprawnienia ani zadania dla Wspólnoty lub Unii ani nie zmienia uprawnień i zadań określonych w traktatach. Jak się wskazuje, rola tego dokumentu ogranicza się do stworzenia jednolitego aktu potwierdzającego prawa wynikające z innych źródeł, a z wielu jej przepisów wyłania się deklaratywny charakter ${ }^{15}$.

W literaturze pojawiły się wątpliwości w kwestii znaczenia przepisu dla roszczeń pracowniczych. Wyrażone zostały odmienne poglądy. L. Florek stwierdził, że przepis Karty ma charakter jedynie blankietowy i nie może stanowić podstawy dla ochrony przed zwolnieniem z pracy ${ }^{16}$. Odmienny pogląd wyraża L. Mitrus, uznając, że przepis art. 30 Karty może stanowić samodzielną podstawę roszczeń pracowniczych ${ }^{17}$. Warto jednak zauważyć, że zakres zastosowania Karty pozostaje niejasny w odniesieniu do Polski z powodu protokołu polsko-brytyjskiego. Art. 30 KPPUE nie odnosi się do konkretnego rodzaju umowy. Przede wszystkim nie wiadomo, czy ochrona została zagwarantowana wszystkim pracownikom, czy tylko zatrudnionym na czas nieokreślony ${ }^{18}$. Pojęcie ochrony, o którym mowa $\mathrm{w}$ art. 30 KPPUE, zostało zagwarantowane wszystkim pracownikom, ale ochrona zagwarantowana poszczególnym pracownikom może wyglądać inaczej w przy-

14 Dyrektywa Rady 99/70/WE z dnia 28 czerwca 1999 roku dotycząca Porozumienia ramowego w sprawie pracy na czas określony, zawartego przez Europejską Unię Konfederacji Przemysłowych i Pracodawców (UNICE), Europejskie Centrum Przedsiębiorstw Publicznych (CEEP) oraz Europejską Konfederację Związków Zawodowych (ETUC) (Dz.U. UE L 1999/175/43).

15 A. Jackiewicz, Problematyka praw człowieka w świetle Karty Praw Podstawowych w aspekcie integracji Polski z Uniq Europejska, „Studia Europejskie” 2003, nr 2, s. 54.

16 L. Florek, Konstytucyjne i prawnomiędzynarodowe podstawy ochrony trwałości stosunku pracy, [w:] Ochrona trwałości stosunku pracy w społecznej gospodarce rynkowej, pod red. G. Goździewicza, Warszawa 2010, s. 45-46.

17 L. Mitrus, [w:] Karta Praw Podstawowych Unii Europejskiej. Komentarz, pod red. A. Wróbla, Warszawa 2013, s. 905-906.

18 A. Rycak, Powszechna ochrona trwałości stosunku pracy, Warszawa 2013, s. 179. Autor ten uznaje, że na podstawie art. 30 Karty Praw Podstawowych UE ochronie podlegają pracownicy zatrudnieni na podstawie umów o pracę na czas nieokreślony (ibidem, s. 184). 
padku umów bezterminowych i umów terminowych ${ }^{19}$. Wprowadzenie dopuszczalności wcześniejszego wypowiedzenia umowy o pracę na czas określony nie musi oznaczać wyłączenia obowiązku uzasadnienia tego wypowiedzenia ${ }^{20}$. Wobec ograniczonego zastosowania Karty Praw Podstawowych UE do Polski należy zauważyć, że także w temacie obowiązku uzasadnienia wypowiedzenia umowy o pracę ustawodawstwo polskie pozostaje pod wpływem prawa unijnego.

Akty prawa międzynarodowego, europejskiego i unijnego szeroko odnoszą się do kwestii ochrony pracownika przed nieuzasadnionym zwolnieniem. Nie przewidują jednak wprost odrębnej regulacji wyraźnie zobowiązującej państwa związane tymi dokumentami do konieczności uzasadniania wypowiedzenia umów o pracę na czas określony. Po pierwsze, przepisy tych dokumentów są dosyć ogólne. Po drugie, jak już zostało wskazane, Polska nie jest nimi związana. Nie należy jednak sądzić, że unormowania prawa międzynarodowego, europejskiego i unijnego pozostają bez wpływu na polski system prawny. Polska jako członek Międzynarodowej Organizacji Pracy, Unii Europejskiej i Rady Europy powinna dążyć do zachowania standardów przyjmowanych w tych organizacjach.

\section{WYPOWIEDZENIE UMOWY O PRACĘ NA CZAS OKREŚLONY WEDŁUG TRYBUNAŁU KONSTYTUCYJNEGO A KIERUNEK ORZECZNICTWA TRYBUNAŁU SPRAWIEDLIWOŚCI UNII EUROPEJSKIEJ}

Trybunał Konstytucyjny nie uznał obowiązujących przepisów o umowie na czas określony za niezgodne z prawem do równego traktowania i niedyskryminacji w stosunkach zatrudnienia oraz z zasadą sprawiedliwości społecznej ${ }^{21}$, przyjmując, że art. 30 § k.p. w zakresie, w jakim pomija obowiązek wskazania przyczyny uzasadniającej wypowiedzenie $\mathrm{w}$ oświadczeniu pracodawcy o wypowiedzeniu umowy o pracę zawartej na czas określony, nie jest niezgodny z art. 2 oraz art. 32 Konstytucji RP. Po orzeczeniu Trybunału Konstytucyjnego w literaturze wyrażane były różne opinie na temat obowiązku uzasadnienia wypowiedzenia umowy o pracę na czas określony. L. Florek uznaje, że Trybunał Konstytucyjny trafnie założył, że art. 30 § 4 k.p. w zakresie, w jakim pomija obowiązek wskazania przyczyny uzasadniającej wypowiedzenie w oświadczeniu pracodawcy o wypowiedzeniu umowy o pracę na czas określony, nie jest niezgodny z art. 2 oraz 32

19 L. Mitrus, Ochrona przed nieuzasadnionym zwolnieniem z pracy $w$ świetle Karty Praw Podstawowych Unii Europejskiej, „Praca i Zabezpieczenie Społeczne” 2012, nr 4, s. 18.

20 Ł. Pisarczyk, Terminowe umowy o pracę, Szansa czy zagrożenie?, „Praca i Zabezpieczenie Społeczne" 2006, nr 8, s. 4.

21 Wyrok Trybunału Konstytucyjnego z dnia 2 grudnia 2008 roku, P 48/07, OTK ZU 2008, nr 10A, poz. 173. 
Konstytucji RP22. Podobne stanowisko prezentuje M. Gersdorf, która stwierdza, że wprowadzenie obowiązku uzasadniania wypowiedzenia umowy o pracę na czas określony prowadziłoby do zburzenia systemu katalogu umów o pracę ${ }^{23}$ L. Mitrus także przychyla się do rozstrzygnięcia Trybunału, wskazując, że różnicowanie zakresu ochrony trwałości stosunku pracy pracowników zatrudnionych na czas określony i nieokreślony nie stanowi naruszenia zasady równego traktowania pracowników ${ }^{24}$.

Z drugiej strony część autorów przychyla się jednak do zdania odrębnego sędzi T. Liszcz, uznając, że przepisy k.p. są niekonstytucyjne w zakresie, w jakim pozbawiają pracowników zatrudnionych na czas określony ochrony służącej osobom zatrudnionym na czas nieokreślony ${ }^{25}$. B. Bury również uważa, że należy opowiedzieć się za uznaniem naruszenia art. 2 i 32 Konstytucji, ponieważ w obecnym stanie prawnym powstaje skutek taki, że w przypadku uzasadnionego wypowiedzenia umowy o pracę na czas nieokreślony, stanowiącego normalny i typowy sposób rozwiązania stosunku pracy, sytuacja pracownika jest zdecydowanie korzystniejsza (w zakresie trybu rozwiązania oraz roszczeń) niż w przypadku pracownika zatrudnionego na podstawie umowy o pracę na czas określony, pomimo że wypowiedzenie tej umowy jest $\mathrm{w}$ prawie pracy wyjątkiem ${ }^{26}$. Podobny pogląd wyraża E. Wronikowska, która opowiada się za koniecznością uzasadniania przez pracodawcę wypowiedzenia umowy o pracę na czas określony na podstawie art. 33 k.p. ${ }^{27} \mathrm{Z}$ wyrokiem Trybunału nie zgadza się także A. Sobczyk, który wskazuje, że długoterminowe zatrudnienia oraz zatrudnienie na czas nieokreślony posiadają istotną cechę wspólną i można mówić o naruszeniu art. 32 Konstytucji ${ }^{28}$.

Warto zauważyć, że od czasu orzeczenia Trybunału Konstytucyjnego upłynęło już trochę czasu, a na temat uregulowania umów o pracę na czas określony w kodeksie pracy wypowiedział się Trybunał Sprawiedliwości Unii Europejskiej.

22 L. Florek, op. cit., s. 44.

23 M. Gersdorf, O przyczynowości zawarcia i rozwiazania umowy na czas określony, [w:] Stosunki zatrudnienia $w$ dwudziestoleciu społecznej gospodarki rynkowej. Ksiega pamiatkowa z okazji jubileuszu 40-lecia pracy naukowej Profesor Barbary Wagner, pod red. A. Sobczyka, Warszawa 2010, s. 225.

${ }^{24}$ L. Mitrus, Kilka uwag o rozwiązaniu za wypowiedzeniem umowy o prace na czas określony, [w:] Stosunki zatrudnienia w dwudziestoleciu społecznej gospodarki rynkowej..., s. 256.

25 J. Litowski, Konstytucyjność zakresu ochrony pracowników przed wypowiedzeniem umowy o pracę na czas określony, „Monitor Prawa Pracy” 2009, nr 8, s. 407.

26 B. Bury, Wypowiedzenie przez pracodawcę umowy o pracę na czas określony - glosa do wyroku Trybunału Konstytucyjnego z dnia 2 grudnia 2008 r., P 48/07, „Monitor Prawa Pracy” 2009, nr 7, s. 383-387.

27 E. Wronikowska, Terminowe umowy o prace a ochrona trwałości stosunku pracy, [w:] Ochrona trwałości stosunku pracy..., s. 194.

28 A. Sobczyk, Prawo pracy w świetle Konstytucji Rzeczpospolitej, t. 2: Wybrane problemy i instytucje prawa pracy a konstytucyjne prawa i wolności czlowieka, Warszawa 2013, s. 244 i n. 
W wyroku z dnia 13 marca 2014 roku $^{29}$ stwierdził on, że zastosowanie różnych długości okresów wypowiedzenia w przypadku umowy o pracę na czas określony i umowy o pracę na czas nieokreślony w polskim porządku prawnym stanowi odmienne traktowanie w kontekście warunków zatrudnienia ${ }^{30}$. Trybunał w odpowiedzi na pytanie prejudycjalne podkreślił, że obiektywnym uzasadnieniem zróżnicowania sytuacji pracowników zatrudnionych na czas określony i nieokreślony, które zgodnie z klauzulą 4 pkt 1 porozumienia ramowego usprawiedliwiałoby różnicę $\mathrm{w}$ traktowaniu tych grup pracowników, nie może być odwołanie jedynie do tymczasowego charakteru zatrudnienia. Trybunał Sprawiedliwości UE, odmiennie niż Trybunał Konstytucyjny, uznał, że zatrudnienie na podstawie umowy o pracę jest cechą relewantną uzasadniającą równe traktowanie pracowników ${ }^{31}$.

Według M. Derlacz-Wawrowskiej pracownicy zatrudnieni na podstawie umowy o pracę na czas określony powinni powoływać się przed sądem pracy na dyrektywę, dążąc do złożenia przez sąd krajowy pytania prejudycjalnego do TSUE dotyczącego zgodności art. $30 \S 4$ k.p. i art. $50 \S 3$ k.p. z klauzulą 4 dyrektywy 70/99/WE. Wprawdzie pytanie sądu polskiego do TSUE dotyczyło jedynie długości okresów wypowiedzenia, ale moim zdaniem pracownicy zatrudnieni na podstawie umowy o pracę na czas określony, którą można wypowiedzieć, mogą przed polskim sądem pracy powoływać się na klauzulę 4 dyrektywy 70/99/WE, twierdząc, że polska regulacja jest niezgodna z dyrektywą i należałoby stosować dyrektywę bezpośrednio w kontekście obowiązku uzasadnienia wypowiedzenia umowy o pracę na czas określony ${ }^{32}$. W przypadku zawarcia umowy o pracę na czas określony z postanowieniem o jej wypowiedzeniu można twierdzić, że tak

29 W wyroku padło pytanie jedynie o długość okresów wypowiedzenia. Zob. wyrok Trybunału Sprawiedliwości Unii Europejskiej z dnia 13 marca 2014 roku w sprawie C-38/13, http://curia. europa.eu/juris/document/document.jsf?text $=\&$ docid $=149140 \&$ pageIndex $=0 \&$ doclang $=$ PL\&mode $=1$ st $\&$ dir $=\&$ occ $=$ first $\&$ part $=1 \& c i d=458269$ [data dostępu: 02.02.2015].

30 Wcześniej również Komisja Europejska w odpowiedzi na skargę NSZZ „Solidarność” wskazywała na różnicę pomiędzy długością okresów wypowiedzenia umów o pracę na czas określony i umów o pracę na czas nieokreślony, która jest niezgodna z unijną dyrektywą. Odpowiedź Komisji Europejskiej jest dostępna pod adresem: www.solidarnosc.org.pl/biura-eksperckie2/kontrola-prawa/komisja-europejska/item/8231-skarga-dot-umow-na-czas-okreslony [data dostępu: 02.02.2015].

31 M. Derlacz-Wawrowska, Glosa do wyroku TSUE z dnia 13 marca 2014 r. w sprawie

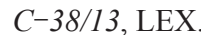

32 T. Liszcz w zdaniu odrębnym wskazuje na art. $18^{3 \mathrm{a}} \S 1$ k.p., który łączy się z klauzulą 4 dyrektywy 99/70/WE. Nie zgadza się z tym L. Mitrus (Kilka uwag o rozwiąaniu..., s. 255), ponieważ uznaje, że prawo do jednostronnego rozwiązania umowy o pracę nie mieści się w pojęciu „warunki pracy”, o którym mowa w klauzuli 4 dyrektywy. Trzeba jednak podkreślić, że art. $18^{3 a}$ $\S 1$ k.p. stanowi, że pracownicy powinni być równo traktowani w zakresie nawiązania i rozwiązania stosunku pracy. Konsekwencją tego rozwiązania, które T. Liszcz uznaje za niezgodne z zasadą równego traktowania, może być choćby zakres przysługujących pracownikom roszczeń w związku $\mathrm{z}$ rozwiązaniem umowy o pracę. 
jak w przypadku umów bezterminowych, należałoby wypowiedzenie umowy na czas określony uzasadnić. Jeśli przepis art. 33 k.p. wprowadza jako zasadę dopuszczalność jego wypowiedzenia, to powinien zostać wprowadzony obowiązek uzasadniania wypowiedzenia umowy o pracę na czas nieokreślony. Powołanie się wprost na dyrektywę przed polskim sądem pracy będzie możliwe w przypadku podmiotów, które są jednostkami państwowymi bądź stanowią emanację państwa $^{33}$. Warto podkreślić, że Sąd Najwyższy powoływał się bezpośrednio na dyrektywę 70/99/WE w zakresie ograniczeń stosowania umów terminowych ${ }^{34}$.

Wprawdzie zakres spraw Trybunału Konstytucyjnego oraz Trybunału Sprawiedliwości UE był różny, jednak mamy do czynienia z dwoma rozbieżnymi wyrokami. O ile Trybunał Konstytucyjny nie uznał sprzeczności z Konstytucją w regulacji umów terminowych, o tyle Trybunał Sprawiedliwości UE uznał, że polskie uregulowanie pozostaje w sprzeczności z dyrektywą unijną. TSUE nie odnosił się jednak do kwestii uzasadnienia wypowiedzenia umów o pracę na czas określony, tylko do długości okresów rozliczeniowych, ale być może jest to kierunek orzecznictwa TSUE, który będzie kontynuowany w kolejnych sprawach.

\section{OBOWIĄZEK UZASADNIENIA WYPOWIEDZENIA UMOWY O PRACĘ NA CZAS OKREŚLONY}

Trzeba zacząć od niebudzącego wątpliwości stwierdzenia, że umowa o pracę na czas określony zakłada istnienie więzi prawnej między stronami tylko przez ściśle oznaczony czas, który jest wyznaczony wolą stron stosunku pracy. Okres obowiązywania umowy o pracę pozostaje w związku z pewnym zdarzeniem mającym nastąpić w przyszłości ${ }^{35}$. Na podstawie art. 30 pkt 4 k.p. umowa o pracę na czas określony rozwiązuje się z upływem czasu, na który była zawarta. Szczególną właściwością tej umowy jest zatem, co do zasady, niedopuszczalność jej wypowiadania ${ }^{36}$.

Kwestia wypowiadania umów terminowych jest przedmiotem dyskusji już od dawna, i to nie tylko w prawie pracy. W prawie cywilnym kontrowersje budzi również dopuszczalność wypowiadania długoterminowych umów zawartych na czas oznaczony $^{37}$. W literaturze prawa cywilnego wskazuje się, że prawo wypo-

33 I. Boruta, Dyrektywy Wspólnoty Europejskiej jako źródło prawa pracy w Polsce, „Praca i Zabezpieczenie Społeczne" 2005, nr 5, s. 2 i n.

34 Kwestia bezpośredniego stosowania dyrektywy jest różnie ujmowana. Zob. wyrok Sądu Najwyższego z dnia 4 października 2011 roku, I PK 56/11, Legalis nr 453479.

35 B. Wagner, Terminowe umowy o prace, Warszawa 1980, s. 18-22, 30-34.

36 U. Jackowiak, Terminowe umowy o prace a ochronna funkcja prawa pracy, „Monitor Prawa Pracy" 2004, nr 4, s. 96-100.

37 Dyskusja toczy się w ogólności, a także wobec konkretnych rodzajów stosunków zobowiązaniowych w odniesieniu do zasady swobody umów. 
wiedzenia przysługuje, co do zasady, w ramach umów zawartych na czas nieoznaczony. Jedynie wyjątkowo ustawodawca zezwala na wypowiedzenie umowy zawartej na czas oznaczony (art. $709^{11}$ k.c. dotyczący umowy leasingu czy art. $869 \S 2$ k.c. odnoszący się do umowy spółki) ${ }^{38}$. W prawie cywilnym za dominującą można uznać koncepcję dopuszczalności wypowiadania trwałych stosunków zobowiązaniowych $\mathrm{z}$ ważnych przyczyn ${ }^{39}$. Jako cechę wyróżniającą dla umów wskazuje się jej trwałość, tj. stabilność - nieprzerwane obowiązywanie stosunku prawnego w ustalonym kształcie przez określony czas ${ }^{40}$. Jak wskazuje doktryna prawa cywilnego, $\mathrm{z}$ cechą trwałości umowy nie jest do pogodzenia swobodne (arbitralne) prawo wypowiedzenia umowy ${ }^{41}$.

Ustawodawca złamał jednak tę zasadę obowiązującą w prawie cywilnym i wprowadził w prawie pracy art. 33 k.p. jako rozwiązanie o charakterze wyjątkowym, choć to prawo pracy powinno przewidywać rozwiązania o charakterze ochronnym względem pracownika. Jak się wydaje, ustawodawca zakładał, że czas trwania umów o pracę na czas określony nie będzie nadmierny, ponieważ zatrudnieniu pracownika na dłuższy czas miała służyć umowa o pracę na czas nieokreślony. W czasie, w którym zaczął obowiązywać kodeks pracy nie zawierano długoletnich umów terminowych, dlatego umowa o pracę na czas określony do 6 miesięcy pozostaje umową niewypowiadalną. W przypadku umów o pracę zawartych na okres dłuższy niż 6 miesięcy przewiduje się dopuszczalność wprowadzenia do umowy postanowienia o wypowiedzeniu. Pamiętać jednak należy, że $\mathrm{w}$ momencie wejścia kodeksu pracy $\mathrm{w}$ życie mieliśmy do czynienia $\mathrm{z}$ inną sytuacją społeczno-gospodarczą, a w latach 90 . XX wieku pracodawcy zaczęli dostrzegać korzyści z dopuszczalności wcześniejszego wypowiedzenia umowy o pracę na czas określony w porównaniu $\mathrm{z}$ wypowiedzeniem umowy o pracę na czas nieokreślony, które powinno być uzasadnione. Niestety, Sąd Najwyższy bardzo szeroko interpretował treść art. 33 k.p., przyjmując, że postanowienie o dopuszczalności wypowiedzenia umowy może zostać wprowadzone w każdym czasie $^{42}$, a jej wypowiedzenie jest możliwe także przed upływem 6 miesięcy ${ }^{43}$. W konsekwencji można dojść do wniosku, że liberalna wykładnia Sądu Najwyż-

38 K. Kopaczyńska-Pieczniak, [w:] A. Kidyba (red.) [et al.], Kodeks cywilny. Komentarz, t. 3: Zobowiązania - część szczególna, Warszawa 2014, s. 874.

39 E. Rott-Pietrzyk, [w:] System Prawa Prywatnego, t. 7: Prawo zobowiąań-część szczegótowa, pod red. J. Rajskiego, Warszawa 2011 (Legalis. Komentarz do art. 764[1] k.c.).

40 Taką cechę wydaje się posiadać umowa o pracę na czas określony, ponieważ ustawodawca zakłada, że ustanie z upływem czasu, na który została zawarta, a zatem istnienie stabilnej więzi prawnej.

${ }^{41}$ R. Trzaskowski, Granice swobody ksztattowania treści i celu umów obligacyjnych. Art. $353^{1}$ k.c., Zakamycze 2005, s. 368-371.

42 Uchwała Sądu Najwyższego z dnia 14 czerwca 1994 roku, I PZP 26/94, OSNAPiUS 1994, nr 8, poz. 126.

43 Wyrok z dnia 7 września 1994 roku, I PZP 35/94, OSNAPiUS 1994, nr 11, poz. 173. 
szego pozbawiła ochrony również pracowników zatrudnionych na czas określony w okresie pierwszych 6 miesięcy zatrudnienia. Zmiana warunków społeczno-gospodarczych doprowadziła do nadużywania art. 33 k.p. do tego stopnia, że w następstwie szerokiego wykorzystania możliwości prawnej stworzonej przez art. 33 k.p., została w praktyce przekreślona istota umowy o pracę na czas określony ${ }^{44}$.

Warto zauważyć, że poza unormowaniem art. 33 k.p. ustawodawca dopuszcza wcześniejsze rozwiązanie umowy o pracę na czas określony w przypadkach wyraźnie określonych w ustawie. W tych też przypadkach konieczne jest wskazanie przyczyny wypowiedzenia umowy o pracę na czas określony. Wypowiedzenie umowy na czas określony oraz umowy na czas wykonania określonej pracy jest możliwe tylko $\mathrm{w}$ przypadkach enumeratywnie określonych w przepisach prawa pracy, przy niedopuszczalności wprowadzania dodatkowych możliwości jej wypowiedzenia w umowie o pracę. Umowy na czas określony zawarte na okres 6 miesięcy i krótszy, umowy na czas określony zawarte powyżej 6 miesięcy, co do których strony nie skorzystały z możliwości wskazanej w art. 33 k.p., oraz umowy na czas wykonania określonej pracy mogą zostać wypowiedziane przed terminem jedynie z przyczyn niedotyczących pracownika. Taka sytuacja nastąpi $\mathrm{w}$ razie ogłoszenia upadłości lub likwidacji pracodawcy (art. $41^{1} \S 2$ k.p.) oraz w przypadkach wskazanych w ustawie z dnia 13 marca 2003 roku o szczególnych zasadach rozwiązywania z pracownikami stosunków pracy z przyczyn niedotyczących pracowników ${ }^{45}$. W tych przypadkach należałoby przyjąć, że nie ma zasadniczych różnic pomiędzy przyczynami uzasadniającymi wypowiedzenie umów terminowych i bezterminowych ${ }^{46}$. W odniesieniu do umowy o pracę na czas określony pracodawca powinien wskazać uzasadnioną przyczynę wypowiedzenia umowy o pracę - przyczynę niedotyczącą pracownika.

Można dostrzec, że ustawodawca w sposób nierówny traktuje pracowników zatrudnionych na czas określony na podstawie umów, w których przewidziane zostały postanowienia o dopuszczalności wypowiedzenia oraz pracowników, w umowach których nie zostały zawarte postanowienia o dopuszczalności wypowiedzenia umowy o pracę. W razie wypowiedzenia umowy o pracę zawartej na czas określony bez postanowienia o dopuszczalności wypowiedzenia będzie możliwe jej wypowiedzenie po zaistnieniu przyczyny niedotyczącej pracownika. W razie umowy o pracę na czas określony, w której postanowienie o wypowiedzeniu zostało wprowadzone, takiej przyczyny pracodawca wskazywać nie musi. Dotyczy to także zakresu roszczeń pracowników. W grupie pracowników zatrudnionych na czas określony można

44 Zob. zdanie odrębne T. Liszcz. Zob. także: L. Mitrus, Kilka uwag o rozwiązaniu..., s. 259.

45 Ustawa z dnia 13 marca 2003 roku o szczególnych zasadach rozwiązywania z pracownikami stosunków pracy z przyczyn niedotyczących pracowników (Dz.U., nr 90, poz. 844 ze zm.), dalej: ustawa z 13 marca 2003 roku.

46 Tak: J. Stelina, [w:] K. Jaśkowski (red.), E. Maniewska, J. Stelina, Grupowe zwolnienia. Komentarz, Warszawa 2007, s. 159. 
zatem doszukać się ich nierównego potraktowania przez ustawodawcę właśnie dlatego, że w przypadku jednych konieczne jest wskazanie przyczyny wypowiedzenia, w przypadku innych takiej przyczyny wskazywać nie trzeba.

Należy również zauważyć, że obecnie pracownicy, którzy zatrudnieni na podstawie umowy o pracę na czas określony zostają zwolnieni za wypowiedzeniem, mają zagwarantowane inne możliwości ustalenia powodu wypowiedzenia ich umowy o pracę. Wobec braku podstawy prawnej do kwestionowania przyczyny wypowiedzenia umowy o pracę pracownik zatrudniony na czas określony może żądać uznania, że doszło do rozwiązania z nim umowy ze względu na dyskryminację. W razie takich roszczeń przed sądem pracy pracodawca będzie musiał wykazać, iż kierował się obiektywnym powodem, rozwiązując z pracownikiem umowę o pracę, a podstawą rozwiązania umowy nie było kryterium dyskryminacji wskazane $\mathrm{w}$ art. $18^{3 \mathrm{a}} \S 1$ k.p. Nawet w bardzo liberalnych systemach prawnych, m.in. w Stanach Zjednoczonych, wprowadza się wyjątek w doktrynie employment at will właśnie oparty na konstrukcji zakazu dyskryminacji z różnych $\operatorname{przyczyn}^{47}$. Nie jest więc tak, że pracodawca, rozwiązując umowę o pracę na czas określony, nie musi liczyć się ze wskazaniem obiektywnego powodu rozwiązania umowy. $Z$ uwagi na rozbudowane przepisy antydyskryminacyjne pracodawca musi liczyć się z koniecznością wykazania przed sądem pracy, że pracownika nie dyskryminował.

W związku z tym, że prawo polskie pozostaje pod wpływem prawa unijnego, ustawodawca polski wskazuje tzw. negatywne przyczyny wypowiedzenia umowy o pracę. Od pewnego czasu ustawodawca wskazuje okoliczności, które nie mogą stanowić przyczyny wypowiedzenia umowy o pracę, przy czym nie ogranicza ich katalogu jedynie do przyczyn wypowiedzenia umowy o pracę na czas nieokreślo$n y^{48}$. Obecnie ten katalog negatywnych przyczyn wypowiedzenia obejmuje trzy przepisy: art. $23^{1} \S 6$ k.p. wyłączający jako przyczynę wypowiedzenia przejście zakładu pracy lub jego części na innego pracodawcę, art. $18^{3 e} \S 1$ k.p. przewidujący skorzystanie przez pracownika z uprawnień przysługujących pracownikowi $\mathrm{w}$ razie naruszenia zasady równego traktowania oraz art. $67^{9}$ k.p. dotyczący odmowy lub rezygnacji z wykonywania telepracy. Są to uregulowania obowiązujące od niedawna. Wszystkie wyłączenia są konsekwencją dostosowania prawa polskiego do prawa unijnego ${ }^{49}$. Pracodawca, wypowiadając umowę o pracę na czas

47 Reguła employment at will, popularna w USA, właśnie w drodze układowej została ograniczona. Zob. A. Rycak, Doktryna employment at will w prawie pracy $w$ Stanach Zjednoczonych, „Praca i Zabezpieczenie Społeczne” 2008, nr 8, s. 11.

48 Tak też: A. Sobczyk, Zakres przedmiotowy negatywnych przyczyn wypowiedzenia umowy o prace, [w:] Stosunki zatrudnienia $w$ dwudziestoleciu społecznej gospodarki rynkowej..., s. 279,285 .

49 Wskazane przepisy są konsekwencją dostosowania prawa polskiego do unijnego, tj. dyrektywa 76/207/WE z dnia 9 lutego 1976 roku w sprawie wprowadzenia w życie zasady równego 
określony, powinien liczyć się z tym, że mimo braku obowiązku uzasadnienia wypowiedzenia tej umowy, nie mogą stanowić przyczyn wypowiedzenia ustawowe negatywne przyczyny wypowiedzenia. $\mathrm{W}$ innym razie będzie to naruszenie przepisów o wypowiadaniu umów o pracę.

\section{UWAGI KOŃCOWE}

Coraz częściej w literaturze postuluje się wprowadzenie zmian w odniesieniu do umów o pracę na czas określony. Jednym z takich postulatów jest wprowadzenie obowiązku uzasadnienia wypowiedzenia umowy o pracę na czas określony. Skoro wypowiedzenie ma charakter wyjątkowy w przypadku umowy o pracę na czas określony, to powinno być także zaopatrzone w obowiązek uzasadnienia wypowiedzenia przez pracodawcę. Należy też zauważyć, że nawet w przypadku umów prawa cywilnego wymaga się istnienia ważnej przyczyny dla wcześniejszego rozwiązania umowy zawartej na czas oznaczony. Zmieniły się także warunki faktyczne i obecna praktyka doprowadziła do zbliżenia się celów/przeznaczenia umów terminowych do umów bezterminowych. Należałoby zatem zaktualizować obecny stan prawny przez wprowadzenie obowiązku uzasadnienia wypowiedzenia także umów o pracę na czas określony. W tym zakresie swoją rolę mogłyby odegrać układy zbiorowe pracy. Warto jednak przewidzieć dopuszczalność wprowadzania pewnych rozwiązań jedynie w treści układu, np. dopuszczalność wypowiedzenia umowy o pracę na czas określony wraz z obowiązkiem podania przez pracodawcę uzasadnionej przyczyny rozwiązania stosunku pracy.

$\mathrm{Z}$ drugiej strony takie rozwiązanie może zostać uznane za zbyt daleko idące, dlatego innym wyjściem mogłoby być wykreślenie art. 33 k.p., co by oznaczało wyłączenie dopuszczalności wcześniejszego rozwiązania umowy o pracę na czas określony za wypowiedzeniem przy zachowaniu obecnych wyjątków w razie zwolnień grupowych, upadłości i likwidacji pracodawcy ${ }^{50}$. Choć i to rozwiązanie bywa w literaturze uznawane za daleko idące i nieodpowiadające obrotowi praw$n^{n e m u}{ }^{51}$, wydaje mi się właściwe, ponieważ przywróciłoby istotę umowie o pracę na czas określony.

traktowania kobiet i mężczyzn w zakresie dostępu do zatrudnienia, kształcenia i awansu zawodowego oraz warunków pracy (Dz.Urz. L 39, 14.o2.1976, s. 40-42); dyrektywa 2001/23/WE z dnia 12 marca 2001 roku w sprawie zbliżania ustawodawstw Państw Członkowskich odnoszących się do ochrony praw pracowniczych w przypadku przejęcia przedsiębiorstw, zakładów lub części przedsiębiorstw lub zakładów (Dz.U. L 82/16); porozumienie ramowe dotyczące telepracy z dnia 16 lipca 2002 roku, tekst dostępny na stronie: www.etuc.org.pl [data dostępu: 08.03.2015].

50 Postuluje się zatem ograniczenie zastosowania art. 33 k.p. jedynie w odniesieniu do pracodawców zatrudniających mniej niż 20 pracowników, wobec których nie ma zastosowania art. 5 ust. 7 ustawy o zwolnieniach grupowych. Zob. Ł. Pisarczyk, op. cit., s. 4.

51 K. Łapiński, Umowa o pracę na czas określony w polskim i unijnym prawie pracy, LEX 2011, s. 123 i n. 


\section{BIBLIOGRAFIA}

Boruta I., Dyrektywy Wspólnoty Europejskiej jako źródło prawa pracy w Polsce, „Praca i Zabezpieczenie Społeczne" 2005, nr 5.

Bury B., Wypowiedzenie przez pracodawcę umowy o pracę na czas określony - glosa do wyroku Trybunału Konstytucyjnego z dnia 2 grudnia 2008 r., P 48/07, „Monitor Prawa Pracy” 2009, nr 7.

Committee of Experts on the Application of Conventions and Recommendations, General Survey Protection against unjustified dismissal (1995), direct request - Spain (1995).

Derlacz-Wawrowska M., Glosa do wyroku TSUE z dnia 13 marca 2014 r. w sprawie C-38/13, LEX.

Florek L., Konstytucyjne i prawnomiędzynarodowe podstawy ochrony trwatości stosunku pracy, [w:] Ochrona trwałości stosunku pracy w spotecznej gospodarce rynkowej, pod red. G. Goździewicza, Warszawa 2010.

Gersdorf M., O przyczynowości zawarcia i rozwiazania umowy na czas określony, [w:] Stosunki zatrudnienia $w$ dwudziestoleciu społecznej gospodarki rynkowej. Ksiega pamiątkowa z okazji jubileuszu 40-lecia pracy naukowej Profesor Barbary Wagner, pod red. A. Sobczyka, Warszawa 2010.

ILO, Protection Against Unjustified Dismissal, General Survey on the Termination of Employment Convention (No. 158) and recomendation (No. 166), Geneva 1995.

ILO, Termination of Employment Instruments, Background paper for the Tripartite Meeting of Experts to Examine the Termination of Employment Convention, 1982 (No. 158), and the Termination of Employment Recommendation, 1982 (No. 166), Geneva 2011.

Jackiewicz A., Problematyka praw człowieka w świetle Karty Praw Podstawowych w aspekcie integracji Polski z Unia Europejska, „Studia Europejskie” 2003, nr 2.

Jackowiak U., Terminowe umowy o pracę a ochronna funkcja prawa pracy, „Monitor Prawa Pracy” 2004, $\mathrm{nr} 4$.

Kopaczyńska-Pieczniak K., [w:] A. Kidyba (red.), Z. Gawlik, A. Janiak, K. Kopaczyńska-Pieczniak, G. Kozieł, E. Niezbecka, T. Sokołowski, Kodeks cywilny. Komentarz, t. 3: Zobowiazania część szczególna, Warszawa 2014.

Litowski J., Konstytucyjność zakresu ochrony pracowników przed wypowiedzeniem umowy o prace na czas określony, „Monitor Prawa Pracy” 2009, nr 8.

Łapiński K., Umowa o pracę na czas określony w polskim i unijnym prawie pracy, LEX 2011.

Mitrus L., [w:] Karta Praw Podstawowych Unii Europejskiej. Komentarz, pod red. A. Wróbla, Warszawa 2013.

Mitrus L., Kilka uwag o rozwiazaniu za wypowiedzeniem umowy o pracę na czas określony, [w:] Stosunki zatrudnienia $w$ dwudziestoleciu społecznej gospodarki rynkowej. Ksiegga pamiątkowa z okazji jubileuszu 40-lecia pracy naukowej Profesor Barbary Wagner, pod red. A. Sobczyka, Warszawa 2010.

Mitrus L., Ochrona przed nieuzasadnionym zwolnieniem z pracy w świetle Karty Praw Podstawowych Unii Europejskiej, „Praca i Zabezpieczenie Społeczne” 2012, nr 4.

Pisarczyk Ł., Terminowe umowy o pracę, Szansa czy zagrożenie?, „Praca i Zabezpieczenie Społeczne" 2006, nr 8.

Rott-Pietrzyk E., [w:] System Prawa Prywatnego, t. 7: Prawo zobowiazań-część szczegółowa, pod red. J. Rajskiego, Warszawa 2011.

Rycak A., Doktryna employment at will w prawie pracy w Stanach Zjednoczonych, „Praca i Zabezpieczenie Społeczne" 2008, nr 8.

Rycak A., Powszechna ochrona trwałości stosunku pracy, Warszawa 2013.

Schömann I., Labour Law Reforms in Europe: Adjusting Employment Protection Legislation for the Worse?, "Working Paper" 2014.02, Brussels 2014.

Sobczyk A., Prawo pracy w świetle Konstytucji Rzeczpospolitej, t. 2: Wybrane problemy i instytucje prawa pracy a konstytucyjne prawa $i$ wolności człowieka, Warszawa 2013. 
Sobczyk A., Zakres przedmiotowy negatywnych przyczyn wypowiedzenia umowy o prace, [w:] Stosunki zatrudnienia $w$ dwudziestoleciu spolecznej gospodarki rynkowej. Księga pamiatkowa z okazji jubileuszu 40-lecia pracy naukowej Profesor Barbary Wagner, pod red. A. Sobczyka, Warszawa 2010.

Stelina J., [w:] K. Jaśkowski (red.), E. Maniewska, J. Stelina, Grupowe zwolnienia. Komentarz, Warszawa 2007.

Świątkowski A.M., Karta Praw Spotecznych Rady Europy, Warszawa 2006.

Trzaskowski R., Granice swobody ksztaltowania treści i celu umów obligacyjnych. Art. $353^{1}$ k.c., Zakamycze 2005.

Wagner B., Terminowe umowy o prace, Warszawa 1980.

Wronikowska E., Terminowe umowy o pracę a ochrona trwatości stosunku pracy, [w:] Ochrona trwałości stosunku pracy w społecznej gospodarce rynkowej, pod red. G. Goździewicza, Warszawa 2010.

\section{SUMMARY}

The article analyses the problem of termination of fix term employment in Polish labour law. It should be mentioned that lately in Poland number of fixed-term contracts is increasing. The reason of this increase could be that fixed-term contract may be terminated at any time, with two weeks notice regardless of its duration. The employer is neither obliged to present a reason of dismissal. In 2008, Constitutional Tribunal held that regulation about fixed-term employment in Labour Code is consistent with Polish Constitution, but there was one separate opinion of judge T. Liszcz. The purpose of this article is to discuss this issue one more time and provide new arguments, especially that there will be amendment to the Labour Code.

Keywords: fix term employment; reason of termination; justified dismissal 